Volume 8, No.1.3, 2019

International Journal of Advanced Trends in Computer Science and Engineering

Available Online at http://www.warse.org/IJATCSE/static/pdf/file/ijatcse7281.32019.pdf

https://doi.org/10.30534/ijatcse/2019/7281.32019

\title{
Quantitative Infrared Thermography Resolved Leakage Current Problem in Cathodic Protection System
}

\author{
M Riduan B. M Shariff ${ }^{1}$, M.F.L. Abdullah ${ }^{2}$, M Yusop B. A Latiff ${ }^{1}$, Rosly B. Hj. Mat Nor ${ }^{1}$, \\ ${ }^{1}$ PETRONAS Penapisan (Melaka) Sdn. Bhd., Malaysia, riduan_shariff@ petronas.com \\ ${ }^{2}$ Universiti Tun Hussein Onn Malaysia, Malaysia, faiz@uthm.edu.my
}

\begin{abstract}
Leakage current problem can happen in Cathodic Protection (CP) system installation. It could affect the performance of underground facilities such as piping, building structure, and earthing system. Worse can happen is rapid corrosion where disturbance to plant operation plus expensive maintenance cost. Occasionally, if it seems, tracing its root cause could be tedious. The traditional method called line current measurement is still valid effective. It involves isolating one by one of the affected underground structures. The recent methods are Close Interval Potential Survey and Pipeline Current Mapper were better and faster. On top of the mentioned method, there is a need to enhance further by synthesizing with the latest visual methods. Therefore, this paper describes research works on Infrared Thermography Quantitative (IRTQ) method as resolution of leakage current problem in CP system. The scope of study merely focuses on tracing the root cause of leakage current occurring at the $\mathrm{CP}$ system lube base oil plant. The results of experiment adherence to the hypothesis drawn. Consequently, resolve the problem and recommend betterment for the future.
\end{abstract}

Key words: SACP, ICCP, Kepner Tregoe, rejuvenation.

\section{INTRODUCTION}

Cathodic protection is an electrical method of slowing the rate of corrosion on metallic structures which are in electrolytes such as water or soil. It has vast application of underground metal facilities such as pipelines, underground storage tanks, dams, well casings, steel pilings, ship hulls and underwater structures. It is a scientific method which fights corrosion by use of the same laws which cause the corrosion [1]. Generally, there are two types of CP system which are Impress Current Cathodic Protection (ICCP) and Sacrificial Anode Cathodic Protection (SACP) [2]. The significant different between these two are SACP system employs reactive metals as auxiliary anodes that are electrically connected directly to the steel to be protected. The electro-chemical potential difference between steel and anode causes current to flow in the electrolyte also electron flow from external anode to the reinforcement. Hence, the whole reinforcement becomes more negatively charged cathode and the external anode corrodes sacrificially [3]. Compare to ICCP system where it employs inert anodes and powered by an external source of DC power or Transformer Rectifier Unit (TRU) to impress a current from an external anode onto the cathode surface (structure to be protected). By forcing a direct current into the reinforcement cage, it increases the cathodic reaction, which produces more hydroxyl ions from oxygen and water. These ions migrate through the concrete cover to the anode where they oxidize to produce oxygen and electrons. The electrons then flow through the anode cables and back to the current source [3].

In Oil \& Gas plant, after operating about 25 years, there is a need to reassess the CP system functionality and reliability. This action will tackle remnant life issue and enables the plant CP system back to protective level for another 20 years by improvement in reliability, safety, availability and maintainability [4]. During execution of rejuvenation project of CP system, faced new ICCP system unable to reach protective level [4]. It is means that, the dc current produced by anode bed was leaked or strayed to unintended protected structure [5]. In easy term, we called it as leakage current.

Like its name, leakage current proposes electric current leaks to ground via grounding path. If intended grounding path missing, it is the same current that flows through alternative grounding path connection such as human body. In the Oil \& Gas sector, leakage current potential to power losses, system inefficiency, equipment tripping, electric shock and power supply disturbance. Identification of fault point will be fundamental should furnish proficient and reliable [6]. Locating the root cause of leakage current is difficult by conventional method which are by clamp meter and voltage meter [7][8][9][10][11][12].

In this study, a new technique is proposed. Instead of direct approach that is looking at the leakage current waveforms, this study moving forward with an indirect approach that is looking at the symptom of the leakage currents. The symptom obviously to be studied is heat produced by leakage currents [13]. Conductor like copper, aluminum and most metal will dissipate heat once current pass through [14]. Heat known as thermal is a potential to study regards to leakage current. It is capable to guide us to their closest location and 
consequently assist engineers or technicians to resolve any problems related to leakage current even safer, faster and cheaper [15].

There are several tools that could detect heat and for this study, we use infrared thermography (IRT) gun. Therefore, this paper presents "Infrared Thermography Qualitative method in resolving CP system leakage current problem" as a novel contribution. The objective of this research work is to trace the root cause of leakage current in new ICCP system consequently resolved the said problem. This paper will share about tacit practical solution to said specific problem encountered by project team. It is hope that, this small effort may help engineers in expediting locating root cause of leakage current occur in $\mathrm{CP}$ system and consequently accelerating its rectification works.

\section{LITERATURE REVIEW}

\subsection{Leakage Current Problem in CP system}

The incident is about new commission of CP system unable to achieve protective level causing live underground piping without protection against corrosion. The mentioned problem observed at lube base oil plant on $14^{\text {th }}$ June 2016. Weather condition is good and fair morning. Investigation method applied is Kepner Tregoe hybrid with Tripod Beta. Configuration of related CP system is ICCP with maximum load $42 \mathrm{Adc}$ as can be seen in diagram Figure 1 below.

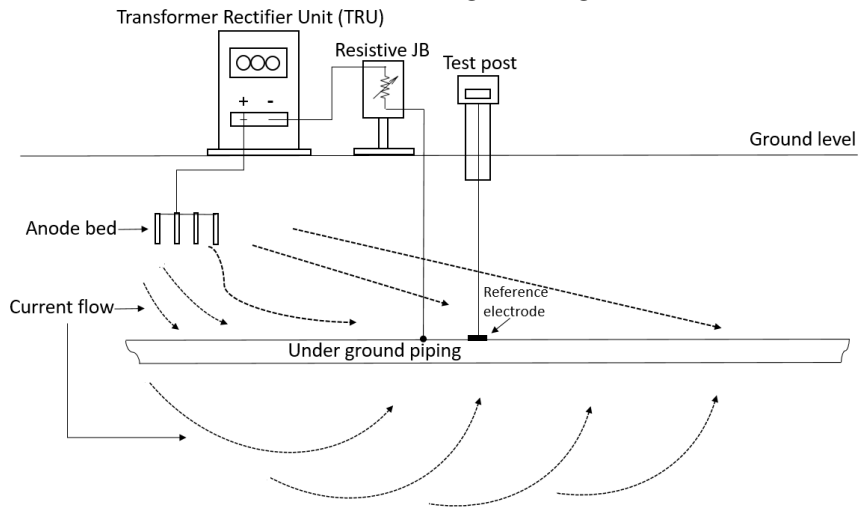

Figure 1: ICCP system diagram

In this method, an external DC power source is supplied from rectifier fed from an AC supply as shown in Figure 1 above between the cathode and sacrificial anode. This method is more efficient for long distances and covering large areas. The anode used is more effective and able to protect long objects. Also, it is very flexible in dealing with soil resistivity variations, because it is capable to supply various required current [16][17].

\subsection{Facts and Findings}

Reflecting to this incident, task force being formed and site verification commence immediately. While waiting for details investigations, preliminary findings as follows:
1) Found two holes (refer red arrow) as effect of localize burning on the top of resistive junction box enclosure at rear side. The junction box made of stainless steel with code SS304. Refer Figure 2 below.

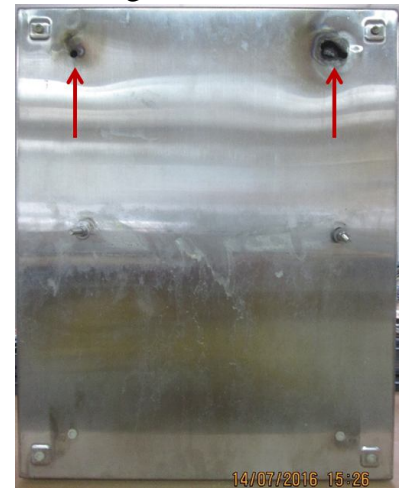

Figure 2: Rear side enclosure

2) Observed two holes (refer red arrow) as effect of localize burning on the top of resistive junction box inside enclosure (as can be look from front access). Refer Figure 3 below.

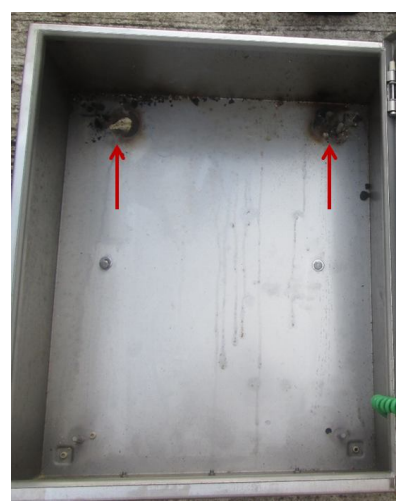

Figure 3: Inside enclosure

3) Heating sign on right and left portion of copper busbar (refer red arrow). Copper busbar act as nodal point for electric current distribution between negative terminal of CP TRU and adjustable resistors. All said components being mounted on Bakelite board (brown color). Refer Figure 4 below.

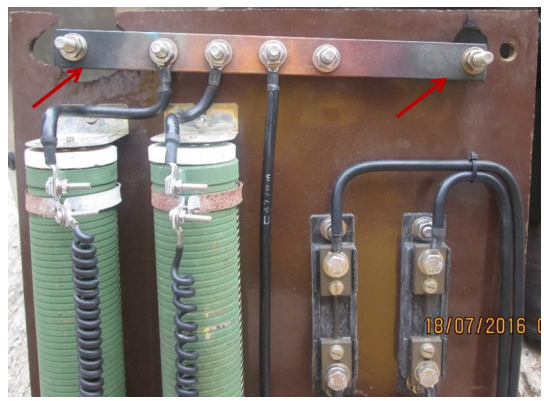

Figure 4: Heating sign on copper busbar

4) Burning sign (refer red arrow) on back side of Bakelite board at the portion perpendicular with heated copper busbar. Round shape vanished as effect of burning. Refer Figure 5 below. 


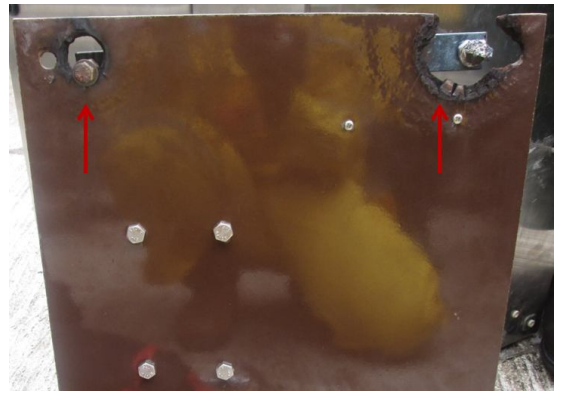

Figure 5: Burning at rear side of Bakelite

The findings above make team wondering what actually happened. Since, the said ICCP system is new and about in commissioning stage. This trigger team to immediate seek information on temperature melting points for each main component. The said information managed to be found in the manuals and datasheet. In short, the information tabulated as per Table 1 below.

Table 1: Melting temperature of resistive junction box components

\begin{tabular}{|c|c|c|}
\hline Component & Materials & $\begin{array}{c}\text { Melting } \\
\text { Temperature }\end{array}$ \\
\hline Enclosure & SS304 & $1400-1455^{\circ} \mathrm{C}$ \\
\hline Mounting Board & Bakelite & $40.5^{\circ} \mathrm{C}$ \\
\hline $\begin{array}{c}\text { Adjustable } \\
\text { Resistor }\end{array}$ & $\begin{array}{c}\text { Lead free vitreous } \\
\text { enamel } \\
\text { (green coating) }\end{array}$ & $750-850^{\circ} \mathrm{C}$ \\
\hline
\end{tabular}

It can be seen that the Bakelite mounting board has lowest melting temperature among all. Meaning, there is something happened that produced heat at temperature more than Bakelite's melting point. The immediate facts and findings shown before couldn't lead us straight forward to the real root cause of the problem. Hence, the systematic approach with assistant of IRT method seems as an alternative way forward.

\subsection{Hypothesis}

Considering the facts \& findings at preliminary stage of investigation and considering from working experience and CP system knowledge, we could draw hypothesis at the best level as flow chart in Figure 6 below.

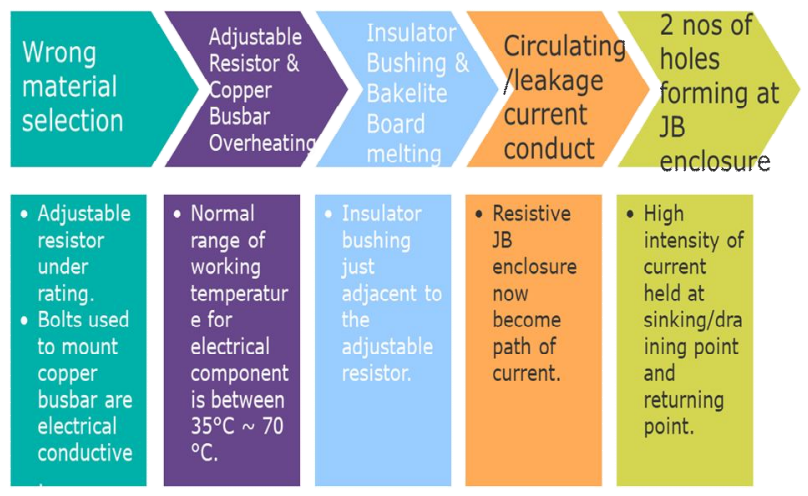

Figure 6: Hypothesis
As to make us excel in investigating the said problem, it is also needing to have basic idea on application of IRT in detecting or tracing the root cause of leakage current. Next section will discuss and explain the recent achievements accordingly.

\subsection{IRT in Tracing Root Cause of Leakage Current}

Thermography is the practice of quantitatively measuring radiative heat emissions from objects. IRT is a field of science of noncontact measurement approach in getting and process the thermal information [18]. Its basis mount on infrared radiation or in other words electromagnetic radiation which have longer wavelengths compared to visible light. The infrared image that captured by infrared cameras then translated into a visible image according to a specific color for each energy level appears as a fake-color image named as a thermogram [19]. It is capable to detect and sense of electrical problems failure or defect. In other form IRT, it is also capable to assist in the medical world [20]. One of an important point, the heat produced because of resistance materials itself. Since electrons in currents flow through resistance, part of energy converted into heat. This makes it possible to use IRT in sensing electrical problems happened [21], [22].

In short, a few kinds of research on IRT for leakage current analysis as follows 1) A nondestructive evaluation of materials by measuring leakage current to check the defect depth despite not knowing its thermal properties and variable surface emissivity [23]. 2) Exact localization of pre-breakdown leakage current distribution in power Schottky diodes [24]. 3) Assess condition of metal-oxide surge arresters via a small resistive leakage current [25], [26]. 4) Detection of leakage current in materials of solar cells [27]. 5) Determine ageing of $\mathrm{ZnO}$ materials in gapless surge arresters [28]. 6) Diagnose leakage current of extremely low value by induced temperature variations down to $10 \mu \mathrm{K}$ at a lateral resolution down to $5 \mu \mathrm{m}$ [29]. 7) Interrogate ac earth fault leakage currents by current waveform probed using special low range current transformer on structure of interest and analyze using Fast Fourier Transform [30], [12].

\section{METHODOLOGY}

Kepner Tregoe method chosen as tool of root cause failure analysis in this effort. It is about rational thinking process that structured, systematic in which used to enhance critical thinking skills during solving the problem, making decision and analysis potential threat or opportunity. Normally referred to as "KT Process" [31]. Here, the actual root cause of the problem and the relationship between cause and result are investigated for (why did it happen) [32]. 


\subsection{Root Cause Failure Analysis - Kepner Tregoe}

We start the Kepner Tregoe analysis by table out the available information into "Is \& Is not" table. Table 2 column "Is", we plug in the problematic equipment data. In conjunction, in the column "Is not" we plug in as much as possible similar healthy equipment. This step will help arrange the data in systematic manner and avoid jumping to wrong conclusion. As well avoid from miss look on the probable factors. Indirectly, the investigation being directed to the right point and lead to time and cost savings. Also, it helps in fast check or verify the correctness of problem statement drawn earlier. Look to the underline statement in Table 2, it is obvious fact that the said problem appears once resistive junction box being replaced with the new one. It is means that, we need to channel much energy and focus on studying the resistive junction box as overall and down to each of its components.

Table 2: Is \& Is not table Kepner Tregoe method

\begin{tabular}{|c|c|c|c|}
\hline & & IS & IS NOT \\
\hline \multirow[t]{2}{*}{ WHAT } & What object? & $\begin{array}{c}\text { Resistive } \\
\text { JUNCTION } \\
\text { BOX tag no. } \\
\text { 18-401, } \\
\text { ICCP \#109, } \\
\text { 18-REC-401 }\end{array}$ & $\begin{array}{c}\text { Other } \\
\text { Resistive } \\
\text { JUNCTION } \\
\text { BOX }\end{array}$ \\
\hline & What deviation? & $\begin{array}{c}\text { Localize } \\
\text { heating }\end{array}$ & Trip \\
\hline WHERE & $\begin{array}{l}\text { Where is the object } \\
\text { when the deviation is } \\
\text { observed } \\
\text { (geographically)? }\end{array}$ & $\begin{array}{l}\text { Unit 18, } \\
\text { MG3 Plant }\end{array}$ & $\begin{array}{l}\text { Unit 19, MG3 } \\
\text { Plant \& others }\end{array}$ \\
\hline \multirow[t]{2}{*}{ WHEN } & $\begin{array}{l}\text { When was the deviation } \\
\text { observed first? }\end{array}$ & $\begin{array}{l}\frac{1 \text { month after }}{\text { resistive }} \\
\text { junction box } \\
\text { been replaced } \\
\text { with new unit } \\
\end{array}$ & $\begin{array}{l}\text { During using } \\
\frac{\text { the old }}{\text { resistive }} \\
\text { junction box }\end{array}$ \\
\hline & Any pattern? & Random & $\begin{array}{l}\text { Continuou } \\
\text { sly or } \\
\text { Periodically }\end{array}$ \\
\hline \multirow[t]{3}{*}{ EXTENT } & $\begin{array}{l}\text { How many objects have } \\
\text { the deviation? }\end{array}$ & $\begin{array}{l}1 \text { unit of } \\
\text { resistive } \\
\text { JUNCTION } \\
\text { BOX } \\
\end{array}$ & $\begin{array}{l}>=2 \text { unit of } \\
\text { resistive } \\
\text { JUNCTION } \\
\text { BOX }\end{array}$ \\
\hline & $\begin{array}{l}\text { How many deviations } \\
\text { are on each object? }\end{array}$ & 1 & $>=2$ \\
\hline & $\begin{array}{l}\text { What is trend in the } \\
\text { number of occurrences } \\
\text { deviations? }\end{array}$ & Stable & $\begin{array}{l}\text { Increase, } \\
\text { Decrease }\end{array}$ \\
\hline
\end{tabular}

\subsection{Possible Causes}

The next step in Kepner Tregoe analysis is to list out reasonable numbers of possible causes at best level of technical knowledge and experiences. Then, eliminate the causes one by one by validating the real facts and findings gathered at site. We called as "Most Possible Causes" for the balance possible causes those couldn't eliminated with available facts and findings. We need to design or assign or sketch any related test, check, validation and way forward action to affirmed either it is the real rot cause or not. The said exercise was tabulated in the Table 3 below for easy and clear mind. We could see that, possible causes number $\mathbf{2}$ and $\mathbf{3}$ now becoming the most probable causes according to assumption made.

Table 3: Possible Causes table Kepner Tregoe method

\begin{tabular}{|c|c|c|c|}
\hline No. & Possible Cause & $\begin{array}{l}\text { Does not explain } \\
\text { (real facts) }\end{array}$ & $\begin{array}{l}\text { Explain only if } \\
\text { (assumption) }\end{array}$ \\
\hline 1 & Lightning strike & $\begin{array}{l}\text { The pattern of the } \\
\text { burning is localized } \\
\text { and concentric as } \\
\text { circle/round shape. } \\
\text { Where else, the } \\
\text { lightning burning } \\
\text { should be in the } \\
\text { pattern of water } \\
\text { treeing or line traces. }\end{array}$ & \\
\hline 2 & $\begin{array}{l}\text { Overheating } \\
\text { due to resistive } \\
\text { junction box } \\
\text { components } \\
\text { under rating } \\
\text { (cable, } \\
\text { adjustable } \\
\text { resistor \& } \\
\text { copper busbar) }\end{array}$ & & $\begin{array}{l}\text { Components selection } \\
\text { for resistive junction } \\
\text { box not suitable to CP } \\
\text { operating current \& } \\
\text { CP TRU rating. }\end{array}$ \\
\hline 3 & $\begin{array}{l}\text { Insulator } \\
\text { bushing melted } \\
\text { lead the bolts } \\
\text { (mount the } \\
\text { busbar to } \\
\text { Bakelite board } \\
\text { and made of } \\
\text { electrically } \\
\text { conductive } \\
\text { material) touch } \\
\text { the resistive } \\
\text { junction box } \\
\text { enclosure and } \\
\text { cause leakage } \\
\text { /circulating } \\
\text { current }\end{array}$ & & $\begin{array}{l}\text { There is current flow } \\
\text { through surface of } \\
\text { enclosure. }\end{array}$ \\
\hline 4 & $\begin{array}{l}\text { Heating up by } \\
\text { hot objects either } \\
\text { touched or close } \\
\text { proximity (< } \\
10 \mathrm{~mm})\end{array}$ & $\begin{array}{l}\text { No any hot } \\
\text { object/equipment/proc } \\
\text { ess line touch and most } \\
\text { about }>1000 \mathrm{~mm} \\
\text { surround resistive } \\
\text { junction box. }\end{array}$ & \\
\hline
\end{tabular}

\subsection{Most Probable Causes}

The following step in Kepner Tregoe method is detailing specific testing or verifying or checking or validating action to be taken according to assumption made earlier. They must be reasonable, technically acceptable and feasible. Here comes the important of IRTQ method to be performed for validating of both most probable causes. It will accelerate the investigation works by qualitatively (comparison) and quantitatively (actual value) of thermogram captured. 
Table 4: Most Probable causes table Kepner Tregoe method

\begin{tabular}{|c|c|c|c|}
\hline No. & $\begin{array}{c}\text { Most Possible } \\
\text { Causes }\end{array}$ & $\begin{array}{l}\text { Explain only if } \\
\text { (assumption) }\end{array}$ & $\begin{array}{c}\text { Testing/Check } \\
\text { to apply }\end{array}$ \\
\hline 2 & $\begin{array}{l}\text { Overheating } \\
\text { due to resistive } \\
\text { junction box } \\
\text { components } \\
\text { under rating } \\
\text { (cable, } \\
\text { adjustable } \\
\text { resistor \& } \\
\text { copper busbar) }\end{array}$ & $\begin{array}{l}\text { Components } \\
\text { selection for } \\
\text { resistive } \\
\text { junction box } \\
\text { not suitable to } \\
\text { CP operating } \\
\text { current \& CP } \\
\text { TRU rating. }\end{array}$ & $\begin{array}{l}\text { 1.Setup the } \\
\text { installation } \\
\text { as original } \\
\text { and put the } \\
\text { CP system } \\
\text { as normal } \\
\text { operating } \\
\text { current. } \\
\text { Perform } \\
\text { Infrared } \\
\text { Thermogra } \\
\text { phy survey. } \\
\text { 2.Check the } \\
\text { rating of } \\
\text { the cable, } \\
\text { adjustable } \\
\text { resistor \& } \\
\text { copper } \\
\text { busbar. Is } \\
\text { it rating } \\
\text { capacity } \\
\text { enough to } \\
\text { meet CP } \\
\text { system } \\
\text { operation } \\
\text { demand? }\end{array}$ \\
\hline 3 & $\begin{array}{l}\text { Insulator } \\
\text { bushing melted } \\
\text { lead the bolts } \\
\text { (mount the } \\
\text { busbar to } \\
\text { Bakelite board } \\
\text { and made of } \\
\text { electrically } \\
\text { conductive } \\
\text { material) touch } \\
\text { the resistive } \\
\text { junction box } \\
\text { enclosure and } \\
\text { cause leakage } \\
\text { /circulating } \\
\text { current }\end{array}$ & $\begin{array}{l}\text { There is current } \\
\text { flow through } \\
\text { surface of } \\
\text { enclosure. }\end{array}$ & $\begin{array}{l}\text { Setup the } \\
\text { installation } \\
\text { as original } \\
\text { and put the } \\
\text { CP system } \\
\text { as normal } \\
\text { operating } \\
\text { current. } \\
\text { Perform } \\
\text { Infrared } \\
\text { thermograp } \\
\text { hy survey. }\end{array}$ \\
\hline
\end{tabular}

\subsection{Experiment Setup}

Experiment was setup as per original installation configuration at site. All cablings related to ICCP system were being wired and terminated properly as normal operation. In addition, suitable clamp meter, temperature detector and humidity detector being hooked-up at the best point those could captured or recorded most actual surroundings intended parameters. The said parameters are surrounding temperature, surrounding humidity, ICCP loading current and thermal image temperature inside the resistive junction box. Once all requirements full-filled and in correct position, it is about to energize power supply and put the ICCP system as real normal operating condition. Setup experiment arrangement as Figure 7. Our assumption for this experiment is surrounding temperature and humidity about same or very slight changes. Also, it must shield from external source of radiation. Because of probing surface temperatures of the sample, it is inevitable closely related to heat flows. Nonetheless, heat flow is closely linked to energy use. In conjunction, other thermal characteristics such as thermal comfort and condensation also linked to surface temperatures [33]. So, these are a few factors to be fixed. Also, it is necessary to prevent surface condensation, which will alter surface emittance and affect performance [33]. In one journal stated the possibility to know the temperature under influence of leakage current that will appear in thermogram later. This new derived equation tells us that the infrared net radiation power is proportional with leakage current, materials resistance, time to reach temperature equilibrium as well as emissivity of the object. But inversely for weight and specific heat capacity of materials. It is presented as (1) below [15].

$\mathrm{T}_{\text {Leakage }}=\left(\mathrm{I}^{2} \cdot \mathrm{R} \bullet \mathrm{t} / \mathrm{m} \cdot \mathrm{Cp}\right)+\mathrm{T}_{\text {No Leakage }}$

Where; I = Current (A); R = Resistance ( $\Omega$ ); $\mathrm{t}=$ Time (s); $\mathrm{m}=$ Weight of Material $(\mathrm{g}) ; \mathrm{Cp}=$ Specific Heat of Material $\left(\mathrm{J} / \mathrm{g} \cdot{ }^{\circ} \mathrm{C}\right)$; Where $\mathrm{T}_{\text {No Leakage }}$ is temperature of the materials during no leakage current passes through it. While, $\mathrm{T}_{\text {Leakage }}$ is temperature of materials during leakage current passes through it [15].

Manipulating (1) above could give (2) as below.

$$
\mathrm{I}_{\text {Leakage }}=\left[\left(\left(\mathrm{T}_{\text {Leakage }}-\mathrm{T}_{\text {No Leakage }}\right) \mathrm{x} \mathrm{m} \cdot \mathrm{Cp} / \mathrm{R} \bullet \mathrm{t}\right)\right]^{1 / 2}
$$

From (2) above, it will enable us to calculate the leakage current value by having temperature profile from thermal image capture later as IRT quantitative measurement.

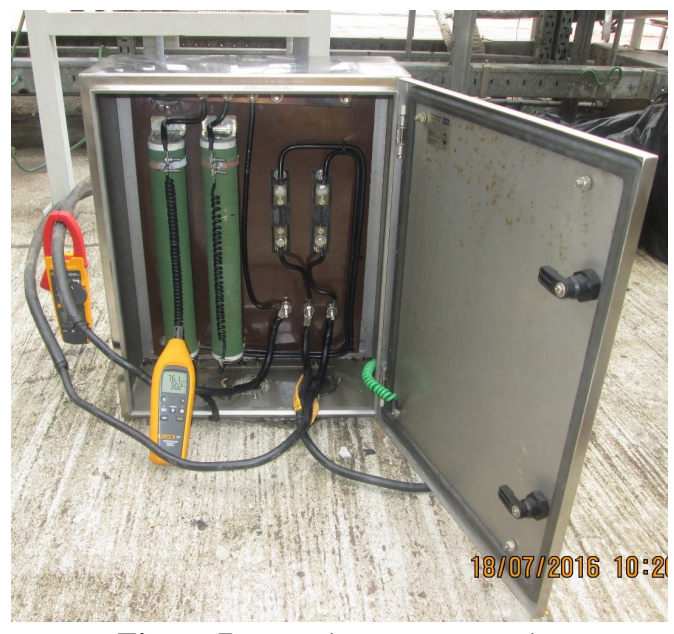

Figure 7: Experiment setup at site 


\section{RESULTS AND DISCUSSION}

Once the ICCP system back on-line, the variac resistance located at CP TRU being rotate or tune in stages from 0Adc until reach 10Adc loading. Testing and checking inside resistive junction box. Then, maintain for a few minutes for capturing thermogram related and $\log$ in parameters as mentioned in the earlier section. Next, the current loading being increase gradually to maximum loading which is 42Adc. This step is important as to simulate as much as similar to actual operating condition and to reveal the hot spot area on the resistive junction box. Two significant area to be investigated are area inside resistive junction box (front access) and its rear side (rear access). All visual results as well numerical shown in Figure $8 \& 9$ and Table $5 \& 6$ follows.

\section{- During 10 Ampere load • During 42 Ampere load (Full Load)}

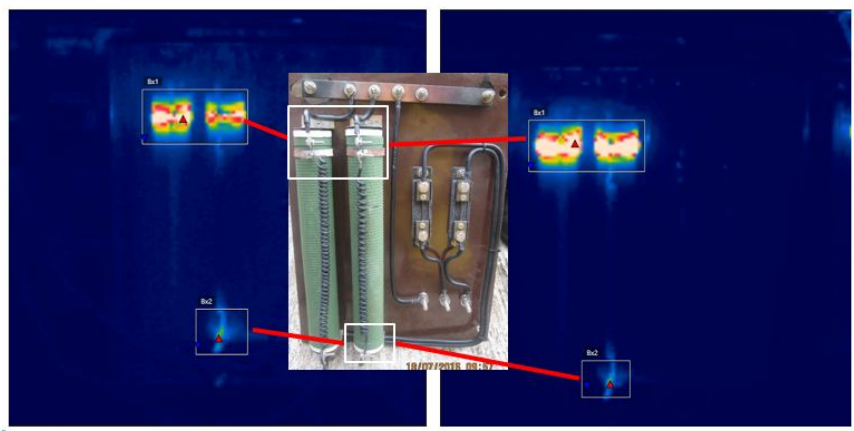

Figure 8: Thermogram inside resistive junction box

Table 5: Temperature profile inside resistive junction box

\begin{tabular}{|l|c|c|c|c|c|c|c|}
\hline \multirow{2}{*}{ No. } & \multirow{2}{*}{$\begin{array}{c}\text { Load } \\
\end{array}$} & \multirow{2}{*}{ A) } & \multicolumn{6}{|c|}{ Thermogram Temperature $\left({ }^{\circ} \mathbf{C}\right)$} \\
\cline { 3 - 8 } & & Min & Max & Ave & Min & Max & Ave \\
\hline 1. & 10 & 33.6 & 110.5 & 52.5 & 31.8 & 52.2 & 35.3 \\
\hline 2. & 42 & 35.9 & 150.2 & 81.8 & 32.4 & 74.8 & 38.5 \\
\hline
\end{tabular}

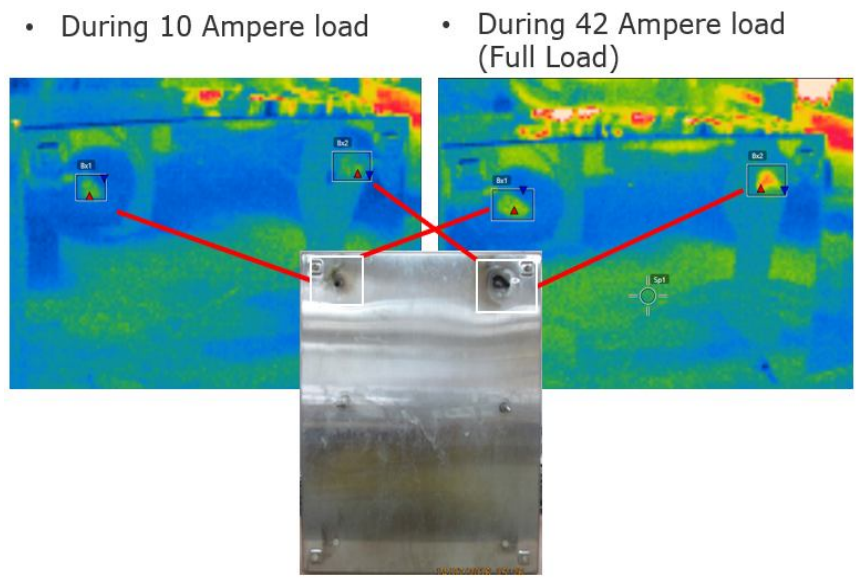

Figure 9: Thermogram rear side resistive junction box
Table 6: Temperature profile rear side resistive junction box

\begin{tabular}{|c|c|c|c|c|c|c|c|}
\hline \multirow[t]{3}{*}{ No. } & \multirow{3}{*}{$\begin{array}{l}\text { Load } \\
\text { (A) }\end{array}$} & \multicolumn{6}{|c|}{ Thermogram Temperature $\left({ }^{\circ} \mathbf{C}\right)$} \\
\hline & & \multicolumn{3}{|c|}{ Box 1} & \multicolumn{3}{|c|}{ Box 2} \\
\hline & & Min & Max & Ave & Min & Max & Ave \\
\hline 1. & 10 & 30.2 & 32.5 & 31.5 & 30.0 & 32.6 & 31.6 \\
\hline 2. & 42 & 30.5 & 33.1 & 31.8 & 31.2 & 36.0 & 32.6 \\
\hline
\end{tabular}

Surrounding temperature recorded at $27.6^{\circ} \mathrm{C}$ with $82 \%$ humidity.

\section{Thermogram results inside resistive junction box}

Due to the temperature rise quite high up to $150^{\circ} \mathrm{C}$ during 10Adc loading and considering the safety at process area; hence we just conduct the simulation for 10 seconds only. There is a sign of component overheating i.e. adjustable resistor. This showing the high probability of components under rating i.e. adjustable resistor. Due to short duration held for the simulation, we cannot see the heating effect at the copper busbar as well at Bakelite board. We could make inference that the copper busbar and Bakelite board will get heated and lead to insulator bushing melted as in Figure 10.

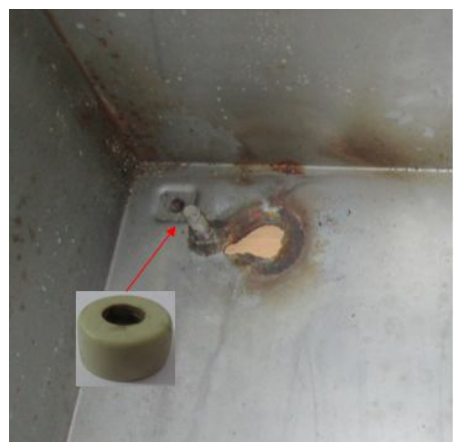

Figure 10: Insulator bushing gone

\section{Thermogram results rear side resistive junction box}

The slight temperature difference and increment at overall from 10A load to $42 \mathrm{~A}$ load (as well compare to surrounding temperature) signifying that there is a leakage or circulating current flowing through the junction box enclosure surface. Please note that due to short duration held for the simulation, we cannot see the great heating effect by the flowing of current. 2 numbers of temperature spot detected showing the area of a bit high current intensity. The right side (Box 2) could be consider as drain/sink point due to higher temperature compare to left side and return point at the left side (Box 1). This finding in-line with the burning condition of the junction box enclosure where the right side (Box 2) had a bigger of hole size compare to left side (Box 1).

\section{Testing and checking (Components Rating)}

From the experiments results above, it requires us to revisit the rating for 3 main components inside resistive junction box 
which are adjustable resistor, copper busbar and adjustable resistor's cable itself. The information being seek from catalogue, datasheet as well general guideline as alternative references and table out as per Table 7 below. Surprisingly, the adjustable resistor is under rating in which not meeting site requirements.

Table 7: Design rating of resistive junction box components

\begin{tabular}{|c|c|c|c|c|c|c|}
\hline \multirow[t]{2}{*}{ No. } & \multirow[t]{2}{*}{$\begin{array}{c}\text { Componen } \\
\mathbf{t}\end{array}$} & \multirow[t]{2}{*}{$\begin{array}{c}\text { Catalo } \\
\text { gue }\end{array}$} & \multirow[t]{2}{*}{$\begin{array}{l}\text { Alter } \\
\text { native }\end{array}$} & \multirow[t]{2}{*}{$\begin{array}{c}\text { Specificat } \\
\text { ion }\end{array}$} & \multicolumn{2}{|c|}{$\begin{array}{c}\text { Rating } \\
\text { Capacity }\end{array}$} \\
\hline & & & & & Pass & Fail \\
\hline 1. & $\begin{array}{l}\text { Adjustable } \\
\text { resistor }\end{array}$ & $\sqrt{ }$ & - & D500 & & $\mathrm{x}$ \\
\hline 2. & $\begin{array}{l}\text { Copper } \\
\text { busbar }\end{array}$ & $\mathrm{x}$ & $\begin{array}{l}\text { Gener } \\
\text { al } \\
\text { guidel } \\
\text { ine }\end{array}$ & $\begin{array}{l}25 \mathrm{~mm}(\mathrm{H}) \\
\text { x } 280 \mathrm{~mm} \\
(\mathrm{~W}) \mathrm{x} \\
2 \mathrm{~mm}(\mathrm{D})\end{array}$ & $\sqrt{ }$ & \\
\hline 3. & $\begin{array}{l}\text { Adjustable } \\
\text { resistor's } \\
\text { cable }\end{array}$ & $\begin{array}{l}\text { Not } \\
\text { Availab } \\
\text { le }\end{array}$ & $\begin{array}{l}\text { Gener } \\
\text { al } \\
\text { guidel } \\
\text { ine }\end{array}$ & $\begin{array}{l}1 \mathrm{c} \mathrm{x} \\
2.5 \mathrm{~mm}^{2}, \\
\mathrm{PVC}\end{array}$ & $\sqrt{ }$ & \\
\hline
\end{tabular}

\section{Discussion (Adjustable Resistor)}

Based on the original equipment manufacturer catalogue on adjustable resistor, the maximum current allows are [34]:

- $\mathrm{I}_{\max }=\sqrt{ }(\mathrm{P} / \mathrm{R})$

- We have data:

- $\mathrm{P}=500 \mathrm{~W}$

- $\mathrm{R}=2.6 \mathrm{ohm}$ (the lowest setting as measured using multimeter)

- Hence the maximum current is $I_{\max }=\sqrt{ }(500 / 2.6)=13.87$ Ampere only per resistor.

- So, we have two numbers of same type resistor and $I_{\max }=2$ $\mathrm{x} 13.87=27.74$ Ampere only allow for safe normal operation of adjustable resistor. But as site requirement is 42Adc. Now the circuit already overloading for about $150 \%$ from its safe rating. In consequence, the overheating occurs due to slow rate of heat dissipation. The design allows for 10 times rated wattage for 5 seconds only [34].

- Also, the said catalogue mentioning, the stated wattage rating is for full setting of resistance at $25^{\circ} \mathrm{C}$ free air rating. Setting the lug at an intermediate point reduces the wattage rating by about the same proportion [34]. Example: If the lug is set at half resistance, the wattage is reduced by approx. one-half.

\section{Discussion (Copper busbar)}

Base on the Current Carrying Capacity table guideline titled "Copper for Busbars, Guidance for Design and Installation":

- The table has data for $25 \mathrm{~mm}^{2}$ width $\mathrm{x} 6.3 \mathrm{~mm}$ thickness $\left(158 \mathrm{~mm}^{2}\right.$ area) which is maximum current is 530A. Anyway, ours is $25 \mathrm{~mm}^{2}$ width $\times 2 \mathrm{~mm}^{2}$ thickness $\left(50 \mathrm{~mm}^{2}\right.$ area). Hence, we could use interpolation method to get the maximum current value:

- $158 / 50=530 / \mathrm{I}$;

- Then, $\mathrm{I}=(530 \times 50) / 158$

$$
\mathrm{I}=167.7 \mathrm{~A}
$$

- So, the current copper busbar used is sufficient for maintaining the 42Adc requirement as full load operation for the $\mathrm{CP}$ system as well up to its fullest TRU rating i.e. 70Adc.

\section{Discussion (Adjustable Resistor's Cable)}

Base on the Current Carrying Capacity table for PVC insulated cable BS7671:

- The maximum current carrying allowable, Imax $=27 \mathrm{~A}$ per cable for Reference Method C (Clipped Direct).

- So, the cable used currently is sufficient if maintaining the $42 \mathrm{~A}$ requirement as full load operation for the $\mathrm{CP}$ system. But, bare on mind, if the CP system going to ramp up to its fullest TRU capacity i.e. 70A; The cable size to be increase to the next higher level those could accommodate $35 \mathrm{~A}$ per cable.

\section{Reaffirmation of findings and results}

For the purpose of reaffirmed or retest our hypothesis, we can use another method root cause failure analysis such as Tripod Beta. Based on the results on the checking and simulation we could synergize all the data, evidence obtained and arranged them into form of Tripod Beta in Figure 11.

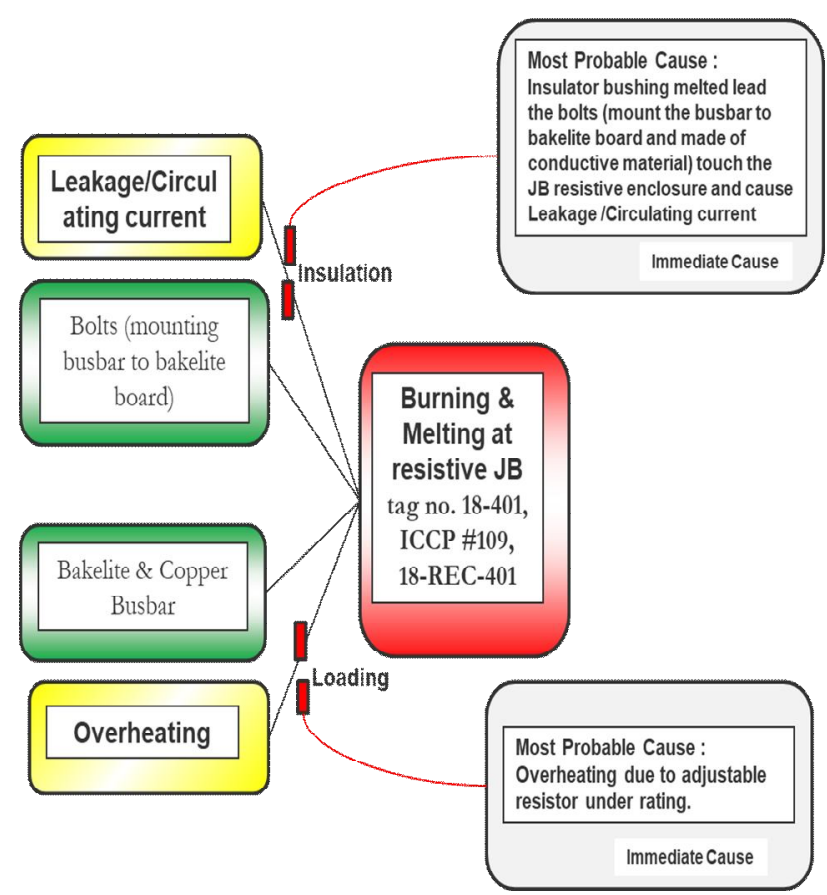

Figure 11: Tripod Beta diagram 


\section{CONCLUSION}

This paper presents resolution of leakage current issues in new ICCP system via Quantitative Infrared Thermography method. The results of the investigation satisfy our hypothesis drawn earlier i.e. due to under rating of adjustable resistor, lead to overheating phenomenon causing Bakelite board and insulator bushing burned \& melted, consequently bolts (those mounting copper busbar onto Bakelite) touching resistive junction box enclosure, make complete circuit and lead to circulating or leakage current on it. Followed by heating (at the sinking \& returning point) and finally impacted burning as 2 numbers of holes at the junction box enclosure body. This incident shows us the importance of the QA/QC assurance during design/selection stage to avoid losses in cost, schedule and reworks. Recommendation are as follows:

- To revisit the selection rating for adjustable resistor as well quantity to accommodate the CP load current comply with $\mathrm{CP}$ TRU rating i.e. 70A for safe and reliable operation.

- To use non-conductive electrical bolt (that mount the copper busbar onto the Bakelite board) to avoid any leakage/circulating current phenomenon through the junction box enclosure in case of the insulating bush degraded/damaged in the future.

- To increase the distance between bolts (that mount the copper busbar onto the Bakelite board) and junction box enclosure by installing dual numbers of insulating bush or equivalent means those could serve the same purpose.

- Any design or materials selection shall be APPROVED by NACE CP Level 4 and endorsed by OWNER prior to purchase and installation at site.

- To consider the derating wattage of the adjustable resistor during tuning at site. To remember half taping at the adjustable resistor, will halves the wattage rating such as $500 \mathrm{~W}$ to $250 \mathrm{~W}$.

\section{ACKNOWLEDGEMENT}

The author would like to recognize contribution by Universiti Tun Hussein Onn Malaysia, Malaysian Refining Company Sdn. Bhd., PETRONAS Penapisan (Melaka) Sdn. Bhd. and who had involved towards accomplishment of this research.

\section{REFERENCES}

[1] J. B. Bushman, "Corrosion and Cathodic Protection Theory," M e d i n a, O h i o 44256 P, USA, 2001.

[2] E. S. Ameh and S. C. Ikpeseni, "Pipelines cathodic protection design methodologies for impressed current and sacrificial anode systems," Niger. J. Technol., vol. 36, no. 4, p. 1072, 2018.

https://doi.org/10.4314/njt.v36i4.12

[3] A. Byrne, N. Holmes, and B. Norton, "Cathodic Protection for Reinforced Concrete Structures: Present Practice and Moves Toward using Renewable
Energy," Corros. Sci., p. 56, 2015.

[4] Asset Life Study and PSR-1 PSR-2 Rejuvenation Project, "Plant Cathodic Protection system survey," Sungai udang, Melaka, Malaysia, 2014.

[5] W. Von Baeckmann, W. Schwenk, W. Prinz, and Editors, Handbook of CATHODIC CORROSION PROTECTION Theory and Practice of Electrochemical protection Processes, Third Edit. Burlington, MA: Gulf Publishing Company, Houston, TX., 1997.

[6] A. Vandana, R. Mohan, A. Abdul, B. Sujatha, and B. N. Kishore, "Fault detection in three phase transmission line using Wavelet Transform algorithm," Int. J. Adv. Trends Comput. Sci. Eng., vol. 8, no. 1, pp. 8-10, 2019.

[7] N. B. Romli, K. N. Minhad, M. B. I. Reaz, and M. S. Amin, "An overview of power dissipation and control techniques in cmos technology," J. Eng. Sci. Technol., vol. 10, no. 3, pp. 364-382, 2015.

[8] I. Condor D.C. Power Supplies, "Condor Application Note 7/01 Leakage Current," 2003. [Online]. Available: www.condorpower.com. [Accessed: 27-Jul-2015].

[9] M. Shariff and M. Abdullah, "Impact of EMI filter installed in AC UPS system to earth leakage current," ... (PEOCO), 2014 IEEE ..., no. March, pp. 647-652, 2014. https://doi.org/10.1109/PEOCO.2014.6814507

[10] A. P. Kumar, B. L. V. S. S. Aditya, G. Sony, C. Prasanna, and A. Satish, "Estimation of power and delay in CMOS circuits using LCT," Indones. J. Electr. Enginering Comput. Sci., vol. 14, no. 2, pp. 990-998, 2019. https://doi.org/10.11591/ijeecs.v14.i2.pp990-998

[11] M. R. M Shariff, M. F. . Abdullah, M. Y. A Latiff, M. Ahmad, and I. Ismail, "Detecting leakage current by infrared thermography method," Indones. J. Electr. Enginering Comput. Sci., vol. 16, 2019.

[12] M. R. Mohd Shariff, M. F. L. Abdullah, Z. A. Haron, A. Johari, M. Y. A. Latiff, and N. E. M. Isnain, "Earthing Current Signature Analysis in resolving Motor Protection Relay communication fault," in Conference Proceeding - 2014 IEEE International Conference on Power and Energy, PECon 2014, 2014, pp. 400-405. https://doi.org/10.1109/PECON.2014.7062478

[13] M. R. B. M. Shariff, M. F. L. Abdullah, and M. Y. B. A. Latiff, "Leakage Current In Eyes Of Infrared Thermography," in 1st International Conference On Information Science \& Communication Technology 2019, 2019.

[14] P. Singh, A. Singh Oberoi, and P. Nijhawan, "Experimental heat transfer analysis of Copper oxide nanofluids through a straight tube," Int. J. Adv. Trends Comput. Sci. Eng., vol. 8, no. 3, pp. 495-500, Jun. 2019.

https://doi.org/10.30534/ijatcse/2019/24832019 
[15] M. R. B. M. Shariff, M. F. L. Abdullah, M. Y. B. A. Latiff, A. B. Mohamad, and I. B. Ismail, "Detecting Leakage Current By Infrared Thermography Method," Indones. J. Electr. Eng. Comput. Sci., vol. 16, no. 1, pp. 1-16, 2019.

[16] S. A. H. Mohammed and I. M. Abdulbaqi, "Numerical Study and Design of an Impressed Current Cathodic Protection System for Buried Metallic Pipes," in 2018 3rd Scientific Conference of Electrical Engineering, SCEE 2018, 2018, pp. 95-100.

https://doi.org/10.1109/SCEE.2018.8684076

[17] D. Lauria, M. Pagano, C. Petrarca, and C. Pisani, "A novel approach to design cathodic protection system for high-voltage transmission cables," IEEE Trans. Ind. Appl., vol. 51, no. 6, pp. 5415-5420, 2015.

https://doi.org/10.1109/TIA.2015.2411735

[18] Z. Azmat and D. J. Turner, "Infrared thermography and its role in rural utility environment," $\mathrm{p}$. B2/1-B2/4, 2005.

[19] P. Venegas, J. Guerediaga, L. Vega, and J. Molleda, "Infrared Thermography for Temperature Measurement and Non-Destructive Testing," Sensors, vol. 14, pp. 12305-12348, 2014.

https://doi.org/10.3390/s140712305

[20] R. Biswas and S. Roy, "Content Based CT Image Sign Retrieval using Fast Discrete Curvelet Transform and Deep Learning," Int. J. Adv. Trends Comput. Sci. Eng., vol. 8, no. 3, pp. 854-863, Jun. 2019. https://doi.org/10.30534/ijatcse/2019/80832019

[21] A. G. Corporate, C. Kolakowski, and R. C. Manager, "Infrared Thermography: Determining failure or problems in electrical systems," 2011.

[22] Infraspection Institute, "Standard for Infrared Inspection of Electrical Systems \& Rotating Equipment," 425 Ellis Street Burlington, NJ 08016, 2008.

[23] R. G. and S. Tuli, "Electrical approach to defect depth estimation by stepped infrared thermography," in IEE Proc.-Sci. Meas. Technol, 2004, vol. 151, no. 4, pp. 298-304.

https://doi.org/10.1049/ip-smt:20040564

[24] M. Riccio, A. Irace, and G. Breglio, "Lock-in thermography for the localization of prebreakdown leakage current on power diodes," in 2009 Ph.D. Research in Microelectronics and Electronics, PRIME 2009, 2009, pp. 208-211.

https://doi.org/10.1109/RME.2009.5201357

[25] Z. Abdul, N. Bashir, and N. Asilah, "Jurnal Teknologi Full paper Thermal Image and Leakage Current Diagnostic as a Tool for Testing and Condition Monitoring of ZnO Surge Arrester," vol. 4, no. Figure 1, pp. 27-32, 2013.

[26] W. A. M. Ursine, J. L. Silvino, L. G. Fonseca, and R. M. De Andrade, "Metal-oxide surge arrester's leakage current analysis and thermography," in 2013 International Symposium on Lightning Protection,
SIPDA 2013, 2013, pp. 297-303. https://doi.org/10.1109/SIPDA.2013.6729238

[27] Y. Hu, "High-Resolution Lock-in Thermography Investigation on Industrial Multicrystalline Silicon Solar Cells," IEEE J. PHOTOVOLTAICS, vol. 3, no. 3, pp. 952-956, 2013. https://doi.org/10.1109/JPHOTOV.2013.2255733

[28] Y. Novizon and A.-M. Zulkurnain, "Correlation between third harmonic leakage current and thermography image of zinc oxide surge arrester for fault monitoring using artificial neural network," Appl. Mech. Mater., vol. 554, pp. 598-602, 2014. https://doi.org/10.4028/www.scientific.net/AMM.554.598

[29] S. Huth, O. Breitenstein, and A. Huber, "Lock-in IR-thermography-A novel tool for material and device characterization," 2002.

https://doi.org/10.4028/www.scientific.net/SSP.82-84.741

[30] M. R. B. M. Shariff, M. F. L. Abdullah, M. Y. B. A. Latiff, G. B. M. Tion, Z. A. Haron, and A. Johari, "Impact of EMI Filter installed in AC UPS System to Earth Leakage Current," in 2014 IEEE 8th International Power Engineering and Optimization Conference (PEOCO2014), Langkawi, The Jewel of Kedah, Malaysia., 2014, no. March, pp. 647-652. https://doi.org/10.1109/PEOCO.2014.6814507

[31] H. Y. Hou, T. H. Hou, and H. J. Hu, "Social intelligence in digital library guide designers," in 2008 IEEE International Conference on Industrial Engineering and Engineering Management, IEEM 2008, 2008, no. 2007, pp. 1249-1252.

https://doi.org/10.1109/IEEM.2008.4738070

[32] ToolsHero.com, "Kepner Tregoe Method," ToolsHero.com, 2019. [Online]. Available: https://www.toolshero.com/problem-solving/kepnertregoe-method/. [Accessed: 01-Jul-2019].

[33] D. Türler, B. T. Griffith, and D. K. Arasteh, "LABORATORY PROCEDURES FOR USING INFRARED THERMOGRAPHY TO VALIDATE HEAT TRANSFER MODELS," California, USA, This work was supported by the Assistant Secretary for Energy Efficiency and Renewable Energy, Office of Building Technology, State and Community Programs of the U.S. Department of Energy under Contract No. DE-AC03-76SF00098., 1997.

[34] OHMITE, "210 Series Dividohm Vitreous Enamel Adjustable Power," OHMITE. OHMITE, pp. 210-210, 2016. 